\title{
Угруповання турунів лісових екосистем природного заповідника «Горгани»
}

У статті представлено дослідження екологічного розподілу турунів у різних типах лісових екосистем заповідника. Визначено видовий склад турунів на дослідних ділянках. Проаналізовано відмінності в складі домінантів, структурі домінування та сезонній динаміці угруповань турунів, що дасть змогу розробити рекомендації для довгострокового збереження турунів у Карпатському регіоні.

Ключові слова: Carabidae, видове різноманіття, природний заповідник «Горгани».

Постановка наукової проблеми та їі значення. Туруни (Carabidae Latreille, 1802) є важливим компонентом лісових екосистем, зокрема вони беруть участь у процесах грунтоутворення, деструкції органіки, ланцюгах живлення й відіграють домінуючу роль у підтримці балансу екосистеми. Існування карабід, залежить від наявності мертвої деревини та старовікових лісів [11]. Карпатські ліси перебувають під впливом антропогенного тиску (туризм, вирубки). Багато видів наземних комах, а саме туруни, є уразливими, оскільки їх існування залежить від непорушених лісових екосистем. Тому актуальним $є$ вивчення екологічного розподілу турунів у різних типах лісових екосистем заповідника, визначення видового складу, відмінностей у складі домінантів, структурі домінування й сезонній динаміці угруповань турунів. Установлення екологічної структури популяцій турунів дасть змогу спрогнозувати сукцесійні процеси в екосистемах та розробити заходи щодо довгострокового збереження турунів у Карпатському регіоні.

Аналіз досліджень цієї проблеми. Наземні комахи - недостатньо вивчена група, особливо у фізико-географічному районі Довбушанських Горган. Їх існування залежить від наявності мертвої деревини та старовікових лісів. Найбільш численною групою грунтових безхребетних у природному заповіднику «Горгани» є родина Туруни (Carabidae Latreille, 1802) - третя за чисельністю родина ряду твердокрилих. В Українських Карпатах відомо поширення 443 видів (57 \% від фауни турунів України), які належать до 85 родів. [1; 5; 6; 7]. В. Б. Різун наводить загальний список турунів на території заповідника, який складає 107 видів. В. С. Пушкарем доповнено цей список ще дев'ятьма видами, тому загалом він нараховує 116 видів [2; 5; 6; 7].

Мета роботи - визначення видового складу, структури домінування, сезонної динаміки угруповань турунів; установлення екологічної структури популяцій турунів, вивчення екологічного розподілу турунів у різних типах лісових екосистем заповідника.

Матеріали й методи дослідження. Матеріалом для досліджень слугували збори, отримані впродовж 2015 р. за підтримки The Rufford Foundation. Вивчення фауністичного багатства безхребетних тварин лісових екосистем проводили в природному заповіднику «Горгани» та на прилеглих до нього територіях. Мезофауна безхребетних займає важливе місце як один із компонентів лісових екосистем, бере участь у процесах грунтоутворення, деструкції органіки та ланцюгах живлення і є важливою ланкою біорізноманіття [4; 6 ].

На території ПЗ «Горгани» та в охоронній зоні заповідника в межах висот 700-1500 м н. р. м. закладено 10 моніторингових ділянок (рис. 1). Дослідження проводили на території Горганського природоохоронного науково-дослідного відділення природного заповідника «Горгани» й Надвірнянського державного лісового господарства (Максимецьке лісництво). Кожна пробна площа зоологічна включала 10 грунтових пасток.

У дослідженні використовували півлітрові пластикові склянки з діаметром отвора 95 мм, кожна 3 яких закопана в землю рівно з поверхнею грунту чи лісової підстилки. Для фіксації безхребетних тварин посудини на $1 / 4$ заповнено сумішшю $10 \%$ розчину оцту та солі. Збір матеріалу здійснювали через кожні два тижні. Зібраний матеріал фіксували 70 \% розчином спирту [4].

Використані методики, звичайно, охоплюють збором лише певний життєвий простір ценозу. Пастки таких типів дають змогу відловлювати мігруючі види мезофауни підстилки та імаго.

Певне (але не головне) значення має й розміщення пробних площ - вони повинні бути максимально віддалені від населених чи рекреаційних пунктів, тобто мінімально відчувати антропічне навантаження та для порівняння одна дослідна ділянка закладається в зоні значного антропогенного навантаження.

(C) Слободян О., 2016 


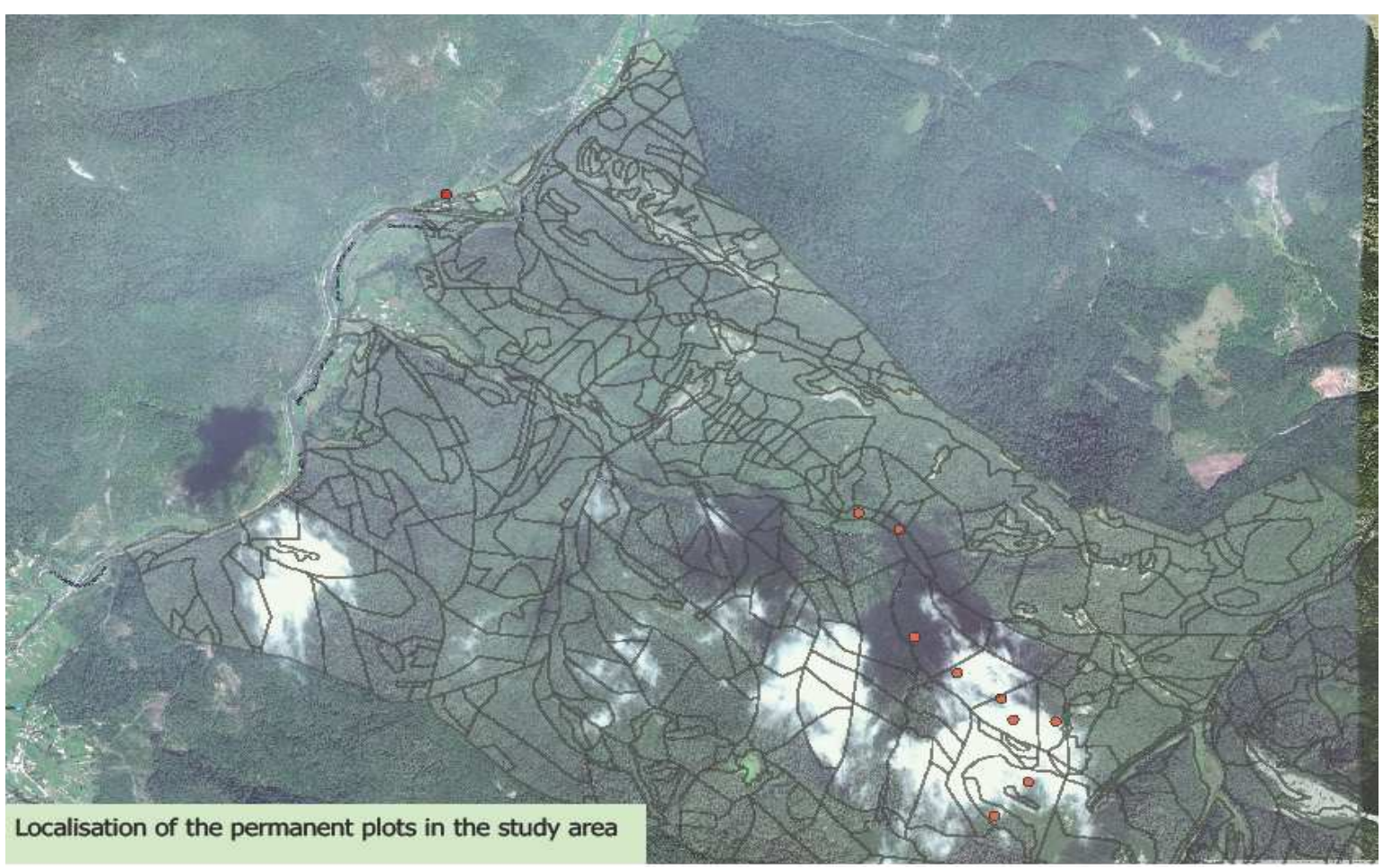

Рис. 1. Розміщення пробних ділянок зоологічних на досліджуваній території

\section{Характеристика пробних площ}

ППП-1. Кількість грунтових пасток - 10. Горганське ПНДВ, кв. 11, вид. 26; 1023 м н. р. м., стрімкість схилу - 15-20. Породний склад деревостану: 4 См4Яц2Бк, поод. Яв, вік дерев - 80-140 років, зімкнутість крон - 0,7-0,9. У підрості трапляються ялиця, смерека, бук, явір, поодиноко граб, у підліску - рідко Sorbus aucuparia, Rosa pendulina, Rubus idaeus, Lonicera nigra, поодиноко - Ribes carpaticum. Трав'яно-чагарниковий ярус синузіально виражений, зімкнутістю до 0,8; домінують Rubus hirtus, Oxalis acetosella, Dryopteris austriaca, Senecio fuchsii, Galeobdolon luteum, Athyrium filix-femina, Galium odoratum, Vaccinium myrtillus. Ступінь покриття мохом - $80 \%$, висота -2 см. Підстилка має товщину до 4 см.

ППП-18. Кількість грунтових пасток - 10. Горганське ПНДВ, кв. 11, вид. 26; 1012 м н. р. м., стрімкість схилу $-21-34^{\circ}$. Породний склад деревостану - 8См2Яц, поод. Бк, Бр., вік дерев - 80-150 років, зімкнутість крон - 0,7-0,9. У підрості трапляються смерека та ялиця, у підліску - Rubus idaeus. У трав'яно-чагарниковому ярусі домінують Dryopteris austriaca, Vaccinium myrtillus. Ступінь покриття мохом $-70 \%$, висота $-1,5-2,5$ см.

ППП-2. Кількість грунтових пасток - 10. Горганське ПНДВ, квартал - 10, виділ - 1; 1160 м, азимут схилу - 240-250 $0^{\circ}$ стрімкість схилу $-24-35^{0}$. Породний склад деревостану - 10 См+Яц, поод. Бк, Яв., вік дерев - 80-180 років, зімкнутість крон 0,7. У підрості трапляються смерека, ялиця, сосна кедрова, у підліску - один відсоток вкриття - Rubus idaeus, поодинико - Rubus hirtus, Zonicera nigra, Sambucus racemosa, Rosa pendulina, Ribes carpaticum, Daphne mezereum i Qrossularia reclinata; висота - 0,4-1,4 м. Трав'яно-чагарниковий ярус синузіально виражений, зімкнутість - 0,8, домінує Luzula sylvatica, Dryopteris austriaca, покриття - 65-70\%. Ступінь покриття мохового й лишайникового покривів суцільний та складає $80 \%$, висота - 2 см.

ППП-3. Кількість грунтових пасток - 10. Горганське ПНДВ, кв. 10, вид. 1, 1280 м, азимут схилу $232^{0}$, стрімкість схилу $-20-25^{0}$. Загальна характеристика грунту, підстилаючих та грунтоутворювальних порід. Бурий гірсько-лісовий середньопотужний суглинковий середньоскелетний опідзолений на елюводелювії карпатського флішу. Породний склад деревостану - $10 \mathrm{CM}+$ Яц, поод. Яв, Кд., вік дерев 150-180 років, зімкнутість крон - 0,6. У підрості склад порід - 6 См2Яц1Яв1Гб, у підліску - $15 \%$ вкриття - Rubus idaeus і поодинико - Lonicera nigra; висота - 0,8-1,2 м, життєвість задовільна. Трав'яно-чагарниковий ярус синузіально виражений, зімкнутість - 0,8, поширення біогрупове; домінують Luzula sylvatica, Dryopteris austriaca, Adenostyles alliariae, Oxalis acetosella. Ступінь покриття мохового покриття складає $80 \%$, висота -2 см. 
ППП-4. Кількість грунтових пасток - 10. Горганське ПНДВ, кв. 10, вид. 1,4; 1310 м н. р. м, азимут схилу - 220-240 ${ }^{\circ}$ стрімкість $25-40^{\circ}$. Породний склад деревостану - 10 См, поод. Яц, вік дерев - 150 років, зімкнутість крон - 0,7. У підрості трапляються смерека, бук, поодиноко граб, у підліску рідко Rubus idaeus, Rosa pendulina, Lonicera nigra. Трав'яно-чагарниковий ярус синузіально виражений, зімкнутістю до 0,7; домінують Dryopteris austriaca, Vaccinium myrtillus. Ступінь покриття мохом - 30 \%, висота -2 см.

ППП- 5. Кількість грунтових пасток - 10. Горганське ПНДВ, кв. 10, вид. 1; 1360 м. н. р. м., азимут схилу $-245^{\circ}$, стрімкість схилу - 35-36, форма рельєфу рівна. Загальна характеристика грунту, підстилаючих та грунтоутворювальних порід: бурий гірсько-лісовий середньопотужний суглинковий опідзолений середньоскелетний у комплексі із сильноскелетним на елюво-делювії карпатського флішу. Породний склад деревостану - 10 См+Кд, поод. Яц, Гб., вік дерев - 100-150 років, зімкнутість крон - 0,8. У підрості трапляються смерека, поодиноко - ялиця та граб, у підліску - рідко Rubus idaeus i поодинико - Ribes carpaticum і Lonicera nigra; висота - 0,8-1,2 м. Трав' яно-чагарниковий ярус синузіально виражений, зімкнутістю до 0,7; домінують Vaccinium myrtillus, Dryopteris austriaca, Homogyne alpina. Ступінь покриття мохом - $90 \%$, висота -2 см.

ППП-6. Кількість грунтових пасток - 10. Горганське ПНДВ, кв.10, вид. 7; 1460 м н. р. м., азимут схилу $-246^{0}$, стрімкість схилу $-35-38^{0}$. Загальна характеристика грунту, підстилаючих та грунтоутворювальних порід: бурий гірсько-лісовий середньопотужний суглинковий опідзолений середньоскелетний у комплексі із сильноскелетним на елюво-делювії карпатського флішу. Породний склад деревостану - 8 См2Кд, поод. Яц, Гб, вік дерев - 50-150 років, зімкнутість крон - 0,8. У підрості трапляються смерека, поодиноко - граб та кедр, у підліску - поодинико Ribes carpaticum і Rubus idaeus. Трав'яно-чагарниковий ярус синузіально виражений, зімкнутістю до 0,5; домінують Vaccinium myrtillus, Oxalis acetosella, Dryopteris austriaca, Homogyne alpina. Ступінь покриття мохом - 80 \%, висота - 2 см.

ППП-9. Кількість грунтових пасток - 10. Горганське ПНДВ, квартал 9, виділ 11; 1470 м н. р. м., азимут схилу $-272^{0}$, стрімкість $-27-34^{0}$, форма рельєфу рівна. Загальна характеристика грунту, підстилаючих та грунтоутворювальних порід: торфувато-гірсько-підзолистий малопотужний суглинковий сильноскелетний на елюво-делювії карпатського флішу. Породний склад деревостану - 6 Кд4См, поод. Яц, Гб., вік дерев - 100-200 років, зімкнутість крон - 0,7-0,8. У підрості трапляються ялиця, смерека, кедр, поодиноко граб, підлісок відсутній. Трав'яно-чагарниковий ярус синузіально виражений, зімкнутістю до 0,4; домінують Vaccinium myrtillus. Ступінь покриття мохом - 100 \% [3].

ППП-1С. Кількість грунтових пасток - 10. Горганське ПНДВ, кв. 9, вид. 9; 1422 м н.р.м. Породний склад деревостану - 10СГ+ЯЛЕ+СКД, вік дерев - 150 років. Схил північно-західної експозиції, 35 градусів, На площі вихід на поверхню кам'янистих порід. Підріст - відсутній. Трав' яно-чагарниковий ярус синузіально виражений, зімкнутістю до 0,25; домінують Vaccinium myrtillus. Ступінь покриття мохом - $100 \%$.

ППП-1 Л. Кількість грунтових пасток - 10. Максимецьке лісництво, Державне підприємство Надвірнянське лісове господарство, кв. 43, вид. 23; 24, 693 м н. р. м. Схил південно-східної експозиції 16 градусів. Породний склад деревостану: лісові культури - 7ЯЛЕ1ОС1БП1ВЛС, ОС, БП, ВЛС природного походження, вік дерев - 50 років. 1976 р. на цих ділянках здійснено суцільну рубку. У 1996 р. була верхова пожежа, у результаті якої змінилися природний склад деревостану й видове різноманіття грунтової фауни.

Виклад основного матеріалу й обгрунтування отриманих результатів дослідження. Загалом проаналізовано 4450 особин безхребетних, які траплялися в грунтових пастках, зокрема 3 них 2421 особина - це туруни. Протягом сезону відловлено безхребетних на пробній площі № $1=783$ особини, № 18 - 289, № 2 - 667 особин, № 3 - 780, № 4 - 666, № 5 - 480, № 6 - 286, № 9 - 194, №1 Л - 65, № $1 \mathrm{C}-240$. Вони $є$ представниками чотирьох класів тварин - Комахи (Insecta), Павукоподібні (Arachnoidea), Двопарноногі (Diplopoda), Губоногі (Chilopoda). Павукоподібні представлені невеликою кількістю екземплярів, що зрозуміло з огляду на методику відлову. Усі Павукоподібні випадково потрапляють у пастки під час міграцій чи розселення, із вітром або падають із крон дерев. Найчисельніші серед жуків - родини Carabidae, Geotrupidae та Silphidae. Загалом же твердокрилі представлені, за попереднім визначенням, 10 родинами. За трофічною спеціалізацією, у вибірці представлені фітофаги (прямокрилі, окремі родини жуків, лускокрилі та певні таксономічні групи перетинчастокрилих) i паразитоїди та більшість комах - сапротрофи (сапрофаги), у тому числі ксилофаги. Фауну жуків-турунів 
на досліджуваній території представлено 18 видами, приналежними до восьми родів. Для аналізу проведено порівняння видового складу й структури домінування турунів на пробних площах (табл. 1). У структурі домінування угруповання турунів на ППП № 1 виявлено три домінуючі види за шкалою Штокера-Бергмана [10], із яких Abax parallelepipedus - 28,26 \%, Carabus obsoletus $(14,4 \%)$, Carabus violaceus (37,5 \%), до субдомінантів належать Carabus auronitens (9,5\%), Pterostichus pilosus (4,89 \%), чисельність інших видів не перевищує $3,1 \%$ і перебуває в межах класів рецидентів та субрецидентів. У структурі домінування угруповання турунів на ППП № 18 виявлено п’яти видів, із яких $A b a x$ parallelepipedus $-10 \%$, Carabus violaceus $-32,5 \%$, Pterostichus pilosus - 21,67 \%, Cychrus caraboides $16,67 \%$ і чисельність інших видів не перевищує $3,1 \%$ та перебуває в межах класу «резиденти й еурециденти». Загалом на території заповідника домінантними видами є Pterostichus pilosus (48,9 \%), Carabus violaceus $(14,13 \%)$, субдомінантами - Abax parallelepipedus $(9,2 \%)$, Ptrostihus foveolatus $(5,53 \%)$, Carabus auronitens (5,49 \%), Carabus linnaei (7,97 \%), Carabus obsoletus (3,39 \%). Чисельність інших видів $€$ нижчою - 3,2 \% - і вони перебувають у межах класу рецедентів й еурецедетів.

Таблиия 1

\section{Видовий склад та структура домінування жуків-турунів (Coleoptera, Carabidae) у різних біотопах на пробних площах, \%}

\begin{tabular}{|c|c|c|c|c|c|c|c|c|c|c|}
\hline \multirow[b]{2}{*}{ Вид } & \multicolumn{10}{|c|}{ Частота трапляння турунів на пробних площах зоологічних, \% } \\
\hline & $\begin{array}{c}\text { ППП } \\
\text { № } 1\end{array}$ & $\begin{array}{c}\text { ППП } \\
\text { № } 2\end{array}$ & $\begin{array}{l}\text { ППП } \\
\text { № } 3\end{array}$ & $\begin{array}{l}\text { ППП } \\
\text { № } 4\end{array}$ & $\begin{array}{l}\text { ППП } \\
\text { № } 5\end{array}$ & $\begin{array}{c}\text { ППП } \\
\text { № } 6\end{array}$ & $\begin{array}{c}\text { ППП } \\
\text { № } 9\end{array}$ & $\begin{array}{l}\text { ППП } \\
\text { № } 18\end{array}$ & $\begin{array}{l}\text { ППП } \\
\text { № 1C }\end{array}$ & $\begin{array}{l}\text { ППП } \\
\text { № 1Л }\end{array}$ \\
\hline 1 & 2 & $\mathbf{3}$ & 4 & 5 & 6 & 7 & 8 & 9 & 10 & 11 \\
\hline $\begin{array}{l}\text { Carabus obsoletus } \\
\text { Sturm, } 1815\end{array}$ & 14,4 & 7,95 & 0,18 & & & & & & & \\
\hline $\begin{array}{l}\text { Carabus linnaei } \\
\text { Panzer, } 1812\end{array}$ & 3,53 & 16,48 & 15,89 & 2,78 & 11,52 & 8,41 & 4 & 2,5 & & \\
\hline $\begin{array}{l}\text { Carabus cancellatus } \\
\text { Illiger, } 1798\end{array}$ & & 1,99 & 1,99 & 0,18 & 2,14 & & & & & \\
\hline $\begin{array}{l}\text { Carabus auronitens } \\
\text { Fabricius, } 1792\end{array}$ & 9,5 & 2,56 & 3,89 & 4,07 & 3,7 & 1,77 & 48 & 15 & 13,51 & \\
\hline $\begin{array}{l}\text { Carabus violaceus } \\
\text { Linnaeus, } 1758\end{array}$ & 37,5 & 26,42 & 10,62 & 0,64 & & 0,44 & & 32,5 & & 44,4 \\
\hline $\begin{array}{l}\text { Carabus coriaceus } \\
\text { Linnaeus, } 1758\end{array}$ & & & & & & & & & & 16,67 \\
\hline $\begin{array}{l}\text { Carabus fabricii ukrainicus } \\
\text { Lazorko, } 1951\end{array}$ & & & & & & & & & 48,65 & \\
\hline $\begin{array}{l}\text { Cychrus caraboides } \\
\text { Linnaeus, } 1758\end{array}$ & 1,63 & 2,27 & 0,71 & 0,43 & 2,47 & & & $16,: 7$ & & 22,22 \\
\hline $\begin{array}{l}\text { Molops piceus } \\
\text { (Panzer, 1793) }\end{array}$ & & 1,99 & 0,88 & 0,64 & 0,82 & & & 0,83 & & \\
\hline $\begin{array}{l}\text { Pterostichus pilosus } \\
\text { (Host, 1789) }\end{array}$ & 4,89 & 15,34 & 60,35 & 83,29 & 69,96 & 76,11 & 24 & 21,67 & 27,03 & \\
\hline $\begin{array}{l}\text { Pterostichus unctulatus } \\
\text { (Duft, 1812) }\end{array}$ & 0,27 & & 0,53 & 0,21 & & & & & & \\
\hline $\begin{array}{l}\text { Pterostichus cordatus } \\
\text { Letzn, } 1852\end{array}$ & & & & & 0,41 & & 20 & 0,83 & 5,41 & \\
\hline $\begin{array}{l}\text { Pterostichus foveolatus } \\
\text { (Duftschmid, 1812) }\end{array}$ & & 1,42 & 9,03 & 4,71 & 9,88 & 13,27 & 4 & & 2,7 & \\
\hline $\begin{array}{l}\text { Pterostichus jurinei heydeni } \\
\text { Dejean, } 1828\end{array}$ & & 0,28 & & & 0,41 & & & & & \\
\hline $\begin{array}{l}\text { Abax parallelepipedus } \\
\text { (Piller \& Mitterpacher, } \\
\text { 1783) }\end{array}$ & 28,26 & 22,73 & 3,19 & 1,07 & 0,82 & & & 10 & & 11,11 \\
\hline $\begin{array}{l}\text { Trichotichnus laevicollis } \\
\text { carpathicus } \text { Schaub, } 1925\end{array}$ & & 0,28 & & & & & & & 2,7 & \\
\hline
\end{tabular}


РОЗДІЛ ІІ. Зоологія. 12, 2016

Закінчення таблииі 1

\begin{tabular}{|l|c|c|c|c|c|c|c|c|c|c|}
\hline \multicolumn{1}{|c|}{$\mathbf{1}$} & $\mathbf{2}$ & $\mathbf{3}$ & $\mathbf{4}$ & $\mathbf{5}$ & $\mathbf{6}$ & $\mathbf{7}$ & $\mathbf{8}$ & $\mathbf{9}$ & $\mathbf{1 0}$ & $\mathbf{1 1}$ \\
\hline $\begin{array}{l}\text { Licinus hoffmannsegii } \\
\text { Panzer, 1803 }\end{array}$ & & 0,28 & 0,18 & & & & & & & \\
\hline $\begin{array}{l}\text { Harpalus rufipes (De Geer, } \\
\text { 1774) }\end{array}$ & & & & & & & & & 5,56 \\
\hline $\begin{array}{l}\text { Усього: } \\
\text { кількість екземплярів }\end{array}$ & $\mathbf{3 6 8}$ & $\mathbf{3 5 2}$ & $\mathbf{5 6 5}$ & $\mathbf{4 6 7}$ & $\mathbf{2 4 3}$ & $\mathbf{2 2 6}$ & $\mathbf{2 5}$ & $\mathbf{1 2 0}$ & $\mathbf{3 7}$ & $\mathbf{1 8}$ \\
\hline Кількість видів & $\mathbf{8}$ & $\mathbf{1 3}$ & $\mathbf{1 2}$ & $\mathbf{1 0}$ & $\mathbf{9}$ & $\mathbf{5}$ & $\mathbf{5}$ & $\mathbf{8}$ & $\mathbf{6}$ & $\mathbf{5}$ \\
\hline
\end{tabular}

Найбільш серед жуків-турунів представлено рід Carabus (сім видів). Спільними для восьми пробних ділянок є лише три види (табл. 1). Найчастіше в пастки потрапляють представники родів Pterostichus, Carabus, Abax, що властиво не лише для Горган, а й лісового поясу Українських Карпат загалом (табл. 2). Оригінальною є знахідка представника роду Carabus - Carabus fabricii ukrainicus. Фауна турунів подібна в досліджених екосистемах буково-ялицево-смерекових (ППП 1) і ялицевосмерекових лісах (ППП 2, 3, 4). Основна відмінність угруповань турунів ППП-1 - це значне різноманіття й велика чисельність представників родини Carabus i Pterostichus, що, імовірно, пов'язано 3 характером підстилки (частка опаду бука більша).

Табличя 2

Систематична структура угруповань турунів на постійних пробних площах зоологічних у природному заповіднику «Горгани» та на прилеглих до нього територіях

\begin{tabular}{|c|c|c|c|c|c|c|c|c|c|c|}
\hline Рід & $\begin{array}{c}\text { ППП } \\
\text { № } 1\end{array}$ & $\begin{array}{c}\text { ППП } \\
\text { № } 2\end{array}$ & $\begin{array}{l}\text { ППП } \\
\text { № } 3\end{array}$ & $\begin{array}{c}\text { ППП } \\
\text { № } 4\end{array}$ & $\begin{array}{c}\text { ППП } \\
\text { № } 5\end{array}$ & $\begin{array}{c}\text { ППП } \\
\text { № } 6\end{array}$ & $\begin{array}{c}\text { ППП } \\
\text { № } 9\end{array}$ & $\begin{array}{l}\text { ППП } \\
\text { № } 18\end{array}$ & $\begin{array}{l}\text { ППП } \\
\text { № 1C }\end{array}$ & $\begin{array}{l}\text { ППП } \\
\text { № } 1 \text { I }\end{array}$ \\
\hline Carabus & 4 & 5 & 5 & 4 & 2 & 3 & 2 & 3 & 2 & 2 \\
\hline Cychrus & 1 & 1 & 1 & 1 & 1 & & & 1 & & 1 \\
\hline Pterostichus & 2 & 3 & 3 & 3 & 4 & 2 & 3 & 2 & 3 & \\
\hline Abax & 1 & 1 & 1 & 1 & 1 & & & 1 & & 1 \\
\hline Molops & & 1 & 1 & 1 & 1 & & & 1 & & \\
\hline Trichotichnus & & 1 & & & & & & & 1 & \\
\hline Licinus & & 1 & 1 & & & & & & & \\
\hline Harpalus & & & & & & & & & & 1 \\
\hline Усього видів: & 8 & 13 & 12 & 10 & 9 & 5 & 5 & 8 & 6 & 5 \\
\hline
\end{tabular}

Для кедрово-смерекового лісу видовий склад турунів, що потрапляють у пастки, є дещо іншим. Для екосистем буково-ялицево-смерекового та кедрово-смерекового лісу коефіцієнт подібності видового складу є низьким і становить 0,3. Найбільш подібними пробними ділянками відповідно до коефіцієнта подібності є ППП1 та ПППЗ $(0,67)$, ППП1 - ППП4 $(0,64)$, ППП2-ППП3 $(0,79)$, ППП5ППП18 $(0,7)$, ППП6-ППП9 $(0,67)$. Для сезонної динаміки властиві періоди збільшення активності турунів на поверхні підстилки протягом вегетаційного сезону (рис. 2-4).

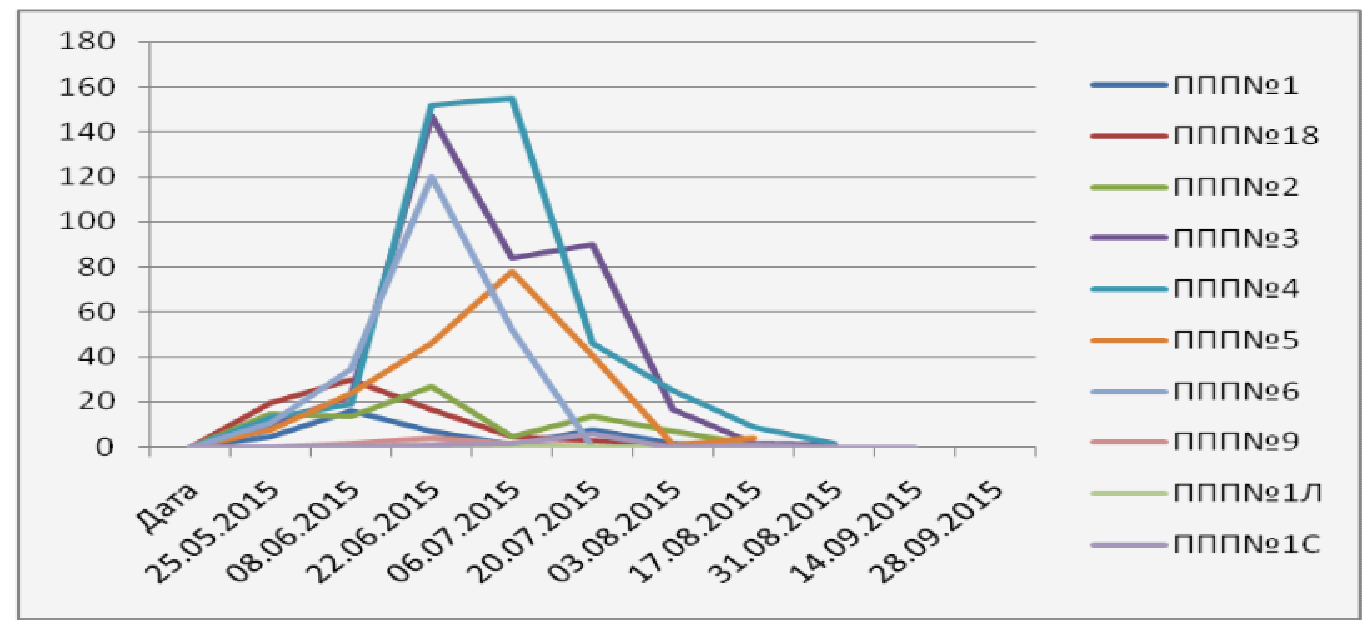

Рис. 2. Динаміка чисельності Pterostichus pilosus (Host) на досліджуваній території 


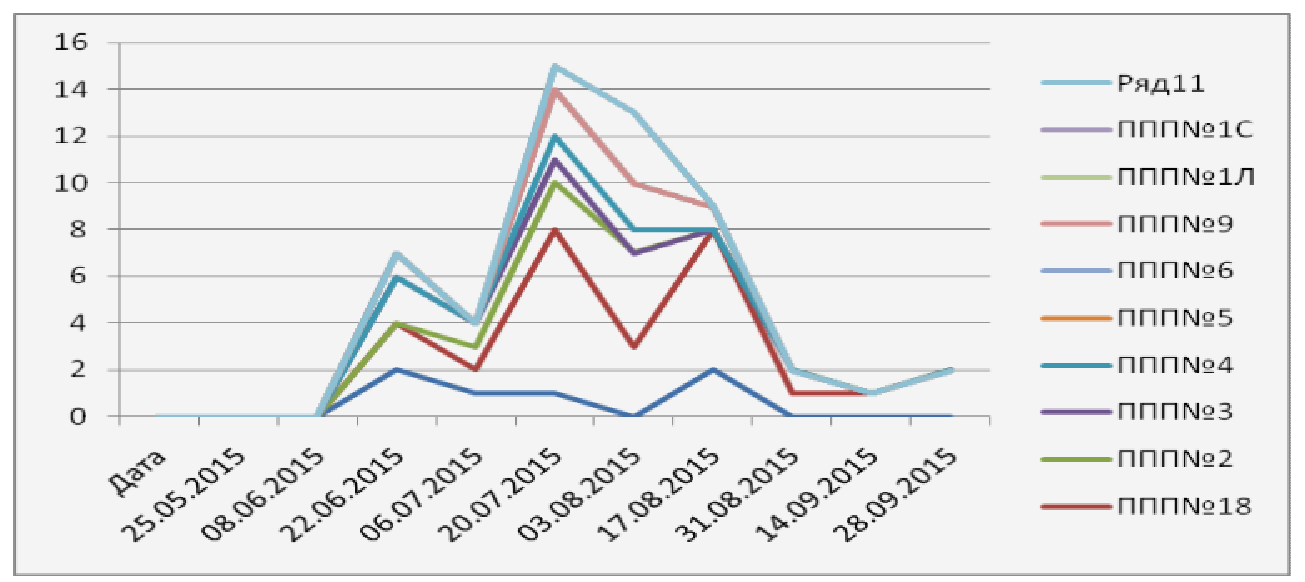

Рис. 3. Динаміка чисельності Cychrus caraboides (L.) на досліджуваній території

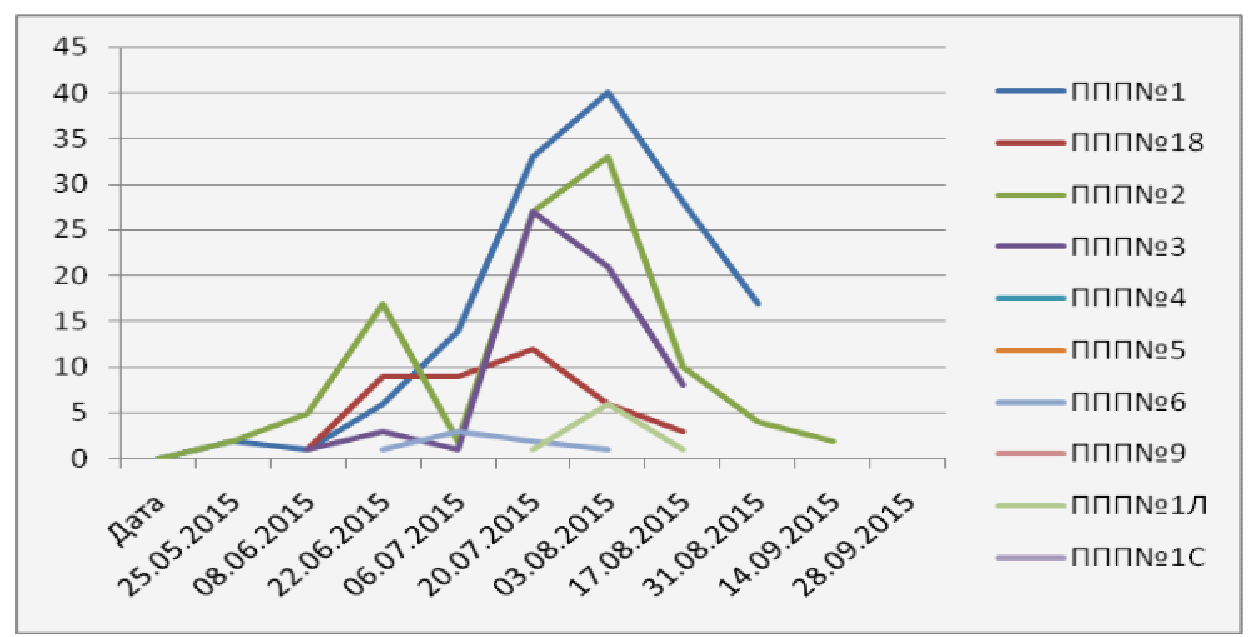

Рис. 4. Динаміка чисельності Carabus violaceus L. на досліджуваній території

Зокрема, динаміка чисельності домінантних видів турунів, таких як Pterostichus pilosus (Host), Carabus violaceus $L, \epsilon$ подібною на ППП 1, ППП3, ППП4, ППП6, оскільки ці пробні площі схожі за типом лісорослинних умов. Порівнюючи вибірки пробних площ, потрібно сказати, що загалом число особин на порядок вище в першій, другій, третій та червертій пробних площах. Тобто простежено чітку залежність від типу досліджуваної екосистеми, типу лісу й висоти над рівнем моря. Більш вологий едатоп сприяє зростанню чисельності окремих таксонів комах.

Висновки та перспективи подальшого дослідження. Склад угруповань турунів на досліджуваній території є типовим для лісового поясу Українських Карпат 3 переважанням на нижчих висотах у буково-ялицево-смерекових лісах (ППП-1) Carabus cancellatus Ill., Carabus obsoletus Strm., Carabus violaceus L., Pterostichus unctulatus (Duft.), Abax parallelepipedus (Pill. et Mitt.), і з переважанням на вищих висотах у ялицево-смерекових та смерекових лісах (ППП 2, ППП 3, ППП 4) видів Carabus linnei Panz., Cychrus caraboides (L.), Pterostichus cordatus Letzn., Pterostichus pilosus (Host) й ін. Потрібно зазначити, що ППП1Л характеризується найменшим видовим різноманіттям і чисельністю, що пов' язано із суцільною рубкою, яку здійснено в 1976 р., та верховою пожежею, що відбулась у 1996 р. у кв. 43 Максимецького лісництва, Надвірнянського лісового господарства. Тому потрібно розробити заходи щодо відновлення та збереження жуків-турунів на цій ділянці.

\section{Джерела та література}

1. Крыжановский О. Л. Жуки подотряда Adephaga семейства Rhysodidae, Trachypachidae; семейство Carabidae (вводная часть, обзор фауны СССР) / О. Л. Крыжановский // Фауна СССР. Жесткокрылые. Л. : Наука, 1983. - № 1. - Вып. 2. - 341 с.

2. Лазорко В. Матеріяли до систематики і фавністики жуків України / В. Лазорко. - Ванкувер : Наук. тов-во ім. Шевченка, 1963. - 200 с. 
3. Олексів Т. М. Науковопізнавальні стежки / Т. М. Олексів // Літопис природи природного заповідника «Горгани». - Т. 3. - Надвірна, 2002. - С. 3-20.

4. Приходько М. М. Фоновий моніторинг навколишнього природного середовища : монографія / М. М. Приходько, М. М. Приходько (старший), Я. О. Адаменко [та ін.]. - Івано-Франківськ : Фоліант, 2010. - 324 с.

5. Пушкар В. С. Доповнення до карабідофауни Природного заповідника «органи» / В. С. Пушкар // Наук. зап. Держ. природознавчого музею. - Львів, 2004. - № 19. - С. 185-186.

6. Ризун В. Б. Семейство Carabidae / В. Б. Ризун // Почвенные членистоногие Украинских Карпат. - Киев : Наук. думка, 1988. - С. 147-160.

7. Різун В. Б. Жуки-туруни (Coleoptera, Carabidae) природного заповідника «Горгани» / В. Б. Ризун // Наук. зап. Держ. природознавчого музею. - Львів, 2002. - o 17. - С. 63-80

8. Різун В. Б. Туруни Українських Карпат / В. Б. Ризун. - Львів, 2003. - 210 с.

9. Jaccard P. Distribution de la flore alpine dans le Bassin des Dranses et dans quelques regions voisines / P. Jaccard // Bull. Soc. Vaudoise sci. Natur. - 1901. - V. 37, Bd. 140. - S. 24-272.

10. Stocker G. Ein Modell der Dominanzstruktur und seine Anwendung. 1 Modelbildung. Modellrealisierung. Dominanzklassen / G. Stocker, A. Bergmann // Arch. Naturchutz. und Landschaftsforschung. - 1977. - Bd. 17, № 1. - S. 1-26.

11. Sustek Zbysek. Carabid communities (Coleoptera: Carabidae) in spruce forest in central Europe/ Zbysek Sustek // Museul Olteniei Craiova. Oltenia. Studii si comunicari. Stiintele Naturii. - T. 29. - № 2. - 2013. P. 140-154.

Слободян Елена. Сообщества жужелиц лесных экосистем природного заповедника «Горганы». Статья включает исследование экологического распределения жужелиц в разных лесных экосистемах заповедника. Определен видовой состав жужелиц на опытных участках. Проанализированы различия в составе доминантов, структуре доминирования и сезонной динамике сообществ жужелиц, что позволит разработать рекомендации для долговременного сохранения жужелиц в Карпатском регионе.

Ключевые слова: Carabidae, видовое разнообразие, природный заповедник «Горгани».

Slobodian Olena. Carabid Communities of Forest Ecosystem of the Gorgany Nature Reserve. The article includes a study of ecological distribution of ground beetles in the different forest ecosystem of the Reserve. It was identified species composition on the permanent plots. The differences in the composition of the dominants, the structure of domination and seasonal dynamics of ground beetles were analyzed. It will a base to develop action plan for long-term conservation of ground beetles in the Carpathian region.

Key words: Carabidae, species diversity, Gorgany Nature Reserve.

Стаття надійшла до редколегії 10.09.2016 р.

УДК 595.771: 614.449 .57

\author{
Катерина Сухомлін, \\ Валерій Капліч, \\ Олександр Зінченко
}

\title{
Сучасні хімічні методи контролю чисельності кровосисних мошок в умовах Українського Полісся
}

У роботі розглянуто ефективність використання сучасних хімічних препаратів із контролю чисельності імаго кровосисних мошок в умовах Українського Полісся. Доведено, що серед репелентів ефективними $\epsilon$ Advantix (крапельно на шкіру вздовж хребта тварини), репеленти виготовлені з місцевої лікарської сировини: багна звичайного (настій із гілок та листя) та пижма звичайного (настій із суцвіть); серед інсектицідів - неостомазан, перметрин, бутокс 200, ектосан ${ }^{\mathrm{TM}}$ і байтикол. Для створення інсектицидного бар'єру навколо ферм, літніх таборів та загонів для утримання тварин потрібно обробляти територію у радіусі до 200 м окурюванням димом (сира трава, шишки) та розприскуванням у радіусі 200 м ємульсій диброму й препарату Байгон 20 К. Е.

Ключові слова: контроль чисельності мошок, репеленти, інсектициди, Полісся.

(C) Сухомлін К., Капліч В., Зінченко О., 2016 